\title{
Niche-based assembly of bacterial consortia on the diatom Thalassiosira rotula is stable and reproducible
}

\author{
Julian Mönnich ${ }^{1} \cdot$ Jan Tebben $\mathbb{D}^{2} \cdot$ Jennifer Bergemann ${ }^{1} \cdot$ Rebecca Case ${ }^{3,4} \cdot$ Sylke Wohlrab ${ }^{2,5} \cdot$ Tilmann Harder $\mathbb{D}^{1,2}$
}

Received: 7 June 2019 / Revised: 3 March 2020 / Accepted: 10 March 2020 / Published online: 23 March 2020

(c) The Author(s) 2020. This article is published with open access

\begin{abstract}
With each cell division, phytoplankton create new space for primary colonization by marine bacteria. Although this surface microenvironment is available to all planktonic bacterial colonizers, we show the assembly of bacterial consortia on a cosmopolitan marine diatom to be highly specific and reproducible. While phytoplankton-bacteria interactions play fundamental roles in marine ecosystems, namely primary production and the carbon cycle, the ecological paradigm behind epiphytic microbiome assembly remains poorly understood. In a replicated and repeated primary colonization experiment, we exposed the axenic diatom Thalassiosira rotula to several complex and compositionally different bacterial inocula derived from phytoplankton species of varying degrees of relatedness to the axenic Thalassiosira host or natural seawater. This revealed a convergent assembly of diverse and compositionally different bacterial inocula, containing up to 2071 operational taxonomic units (OTUs), towards a stable and reproducible core community. Four of these OTUs already accounted for a cumulative abundance of $60 \%$. This core community was dominated by Rhodobacteraceae $(30.5 \%)$, Alteromonadaceae $(27.7 \%)$, and Oceanospirillales $(18.5 \%)$ which was qualitatively and quantitatively most similar to its conspecific original. These findings reject a lottery assembly model of bacterial colonization and suggest selective microhabitat filtering. This is likely due to diatom host traits such as surface properties and different levels of specialization resulting in reciprocal stable-state associations.
\end{abstract}

Supplementary information The online version of this article (https:// doi.org/10.1038/s41396-020-0631-5) contains supplementary material, which is available to authorized users.

$\triangle$ Tilmann Harder

t.harder@uni-bremen.de

1 Marine Chemistry, Department of Chemistry and Biology, University of Bremen, 28359 Bremen, Germany

2 Section Ecological Chemistry, Alfred Wegener Institute, Helmholtz Centre for Polar and Marine Research, 27570 Bremerhaven, Germany

3 Department of Biological Sciences, University of Alberta, Edmonton, AB, Canada

4 Singapore Centre for Environmental Life Sciences Engineering (SCELSE), Nanyang Technological University, Singapore 637551, Singapore

5 Helmholtz Institute for Functional Marine Biodiversity, 23129 Oldenburg, Germany

\section{Introduction}

Marine phytoplankton is pivotal in fixing and converting atmospheric $\mathrm{CO}_{2}$ into biological matter. The organic matter enters the marine food web and is partially exported to the ocean floor, supporting global marine biological and geochemical processes as a consequence [1]. These processes are largely fueled by close interactions between phytoplankton and bacteria and driven by specific bacterial enzymatic capabilities as well as reciprocal needs of bacteria and phytoplankton for essential trace elements, micro-, and macronutrients [2,3]. Experimental evidence for such interactions is demonstrated for the utilization and acquisition of bacterially produced B-vitamins [4] and essential trace metal ions by diatoms [5]. The presumed vitamin $\mathrm{B}_{12}$ auxotrophy of many phytoplankton is confirmed in more than $50 \%$ of investigated stramenopiles [6].

In return for vitamins and other cofactors, phytoplankton offer an organic carbon source to heterotrophic bacteria through cell wall-associated macromolecules and sequestration of photosynthetic products [7]. Diatoms, for example, release up to $5 \%$ of their primary production as 
photosynthate [8]. A high proportion of this dissolved organic carbon consists of high-molecular weight (HMW) components such as polysaccharides [9]. Recent research using phototroph-heterotroph co-culture experiments under nutrient-amended and natural seawater conditions suggests that phytoplankton and bacterial heterotrophs do not compete for the same limited resources, but rather benefit from each other because of very different levels of specialization resulting in complementary associations in long-term stablestate systems [10]. One of these studies revealed feedback loops of bacteria producing algal growth hormones from diatom-derived precursor molecules in exchange for diatomexcreted organosulfur molecules, which in turn stimulate bacterial excretion of ammonia subsequently fueling diatom growth [11]. Despite these sophisticated examples of reciprocal metabolic exchange, the role of these compounds in organismal interactions and in the assembly of bacterial consortia on phytoplankton are poorly studied [7].

The exudation of organic photosynthate molecules by phytoplankton involves passive diffusion driven by a steep concentration gradient between the phytoplankton cell and its surroundings. The diffusive boundary layer causing this gradient is the algal phycosphere [12], which defines the location for direct interactions between microalgae and bacteria. It is largely made up of HMW polysaccharides. Depending on their monomer composition, type and degree of branching and ultrastructure, phytoplankton exopolysaccharides represent highly diverse and often plankton species-specific chemical compounds [13]. These molecules are crucial attractants for heterotrophic bacteria [14]. For bacteria to utilize these exopolysaccharides requires specific carbohydrate-active enzymes [15] encoding the machinery for polysaccharide detection, hydrolysis, and uptake. Such enzymes are localized within gene clusters referred to as polysaccharide utilization loci (PULs). As no single bacterium is adequately specialized to utilize the suite of complex phytoplankton exopolysaccharides, commensal and mutualistic associations of different heterotrophic bacteria with complementary PULs are assumed to co-occur in the phycosphere. This in turn gives rise to the emerging concept of plankton-specific associated consortia [14, 16].

The above examples indicate that an epiphytic bacterial community is important to normal phytoplankton function and, by extension, the ecology of the habitat in which they exist. Indeed, several recent microbiome studies of diverse phytoplankton suggest that marine and fresh water phytoplankton harbor unique bacterial consortia which are consistent within phytoplankton species and across temporal scales [16-19]. Yet, some phytoplankton do not harbor a core set of associated bacteria [20]. In these cases, the sampling time and location are suggested to be more decisive factors determining the associated microbiome than phytoplankton species affiliation [21].
The principles underlying the assembly of complex epiphytic microbial communities have been an issue of longstanding concern to the field of marine microbial ecology. Contrary to microbiome studies of marine microalgae, there are detailed and spatiotemporally replicated studies of epiphytic communities on macroalgal surfaces. The green seaweed Ulva australis, for example, harbors a highly specific associated bacterial community distinct from that of surrounding seawater but with a high degree of variability among $U$. australis individuals [22]. These observations reject the hypothesis of a stable, algal species-specific core microbiome and suggest that a large number of bacterial species colonize this macroalgal surface. Burke et al. [22] linked this conclusion to the redundancy hypothesis [23], which assumes that more than one species is capable of performing a specific role within an ecosystem. Yet, on its own, functional redundancy did not account for observations of both selectiveness and variability, suggesting additional selective mechanisms determining the epiphytic bacterial assemblage on the seaweed. The authors reconciled their observations with the lottery hypothesis [24, 25], an ecological assembly model originally developed to explain the coexistence of reef fish species, that departs from the traditional niche-based view. This theory asserts that species with similar trophic abilities will occupy space within an ecosystem based on stochastic recruitment, i.e., whoever gets there first wins the lottery for space. In $U$. australis, this model entails that a guild of certain bacteria, all of which possess the necessary genetic abilities to colonize and metabolic requirements to live on the thallus surface, is functionally redundant [26]. These considerations are particularly pertinent in the context of microbial community ecology, given the frequent genetic exchange among taxonomically distinct bacteria through horizontal gene transfer, resulting in a high degree of genomic and functional coherence.

There is currently no unifying scheme or theory for bacterial community assembly on marine phytoplankton that satisfies the diverse observations spanning the spectrum from distinct core communities on phylogenetically distant microalgae to spatially and/or temporally diverse communities on conspecific microalgae. Notably, studies addressing bacterial community assembly resulting from interactions between two microscopic players (i.e., phytoplankton and seawater bacteria) are challenging due to the microscopic scale at which they occur. The only studies to date, comparing bacterial assemblages on individual cells of congeneric diatoms obtained from natural waters, found that recovered bacterial phylotypes were extremely diverse and rarely shared across individual diatom cells [27, 28], potentially supporting a lottery assembly model.

We conducted a series of independent and replicated coculture experiments to unravel patterns of bacterial community assembly on a globally important, bloom-forming 
marine diatom genus, Thalassiosira $[29,30]$, specifically a North Sea isolate of $T$. rotula. The diatom was rendered axenic and cultured under micronutrient-poor conditions in the absence of B-vitamins. These axenic $T$. rotula cultures were inoculated with complex bacterial communities detached from conspecific (from the same species), congeneric (from the same genus), and heterospecific (from a different species) co-occurring diatom species and seawater bacterioplankton. Once these co-cultures reached midexponential growth phase, the newly established, primary $T$. rotula microbiomes were sampled and sequenced for biostatistical analyses.

\section{Materials and methods}

\section{Phytoplankton collection, species characterization, and culture maintenance}

Monoclonal phytoplankton batch cultures were established by isolating single cells or chains of microalgae from seawater collected at the island of Helgoland $\left(54^{\circ} 11^{\prime} 03^{\prime \prime} \mathrm{N}, 7^{\circ}\right.$ $54^{\prime} 00^{\prime \prime} \mathrm{E}$ ). The isolates were grown in 12-well plates with filter-sterilized artificial seawater medium (ESAW) containing essential trace metals and vitamins [31] with the exception of $T$. rotula_A17, which was isolated and maintained in vitamin-depleted ESAW. Pure and established cultures were transferred to $25 \mathrm{~mL}$ culture flasks and maintained at $15^{\circ} \mathrm{C}$ and a $12 \mathrm{~h} \mathrm{light} / 12 \mathrm{~h}$ dark diurnal cycle $\left(30-70 \mu \mathrm{mol} \mathrm{m} \mathrm{m}^{-2} \mathrm{~s}^{-1}\right)$. Every week, aliquots of batch cultures were transferred into new medium at a concentration of 2000 cells $\mathrm{mL}^{-1}$ to maintain healthy and exponentially growing cultures. Taxonomic identities of $T$. rotula strain S16 (isolated in spring 2016, in the following labeled $T$. rotula_S16), T. rotula strain A17 (isolated in autumn 2017, in the following labeled $T$. rotula_A17), and axenic $T$. rotula_S16 (see below), were assigned by sequence similarity analysis of a fragment of the small and large subunit of the $18 \mathrm{~S}$ and $28 \mathrm{~S}$ ribosomal RNA gene (see Supplementary section). Briefly, algal pellets were processed with the DNeasy Powersoil kit (Qiagen, Germany) according to the manufacturer's instructions. PCR was performed with specific primers [32, 33]. The other diatom isolates were identified based on morphological characteristics [34] resulting in the assignment of Ditylum brightwellii and Cylindrotheca closterium (isolated in spring 2016). Two other Thalassiosira species, T. weissflogii (CCMP 3365) and T. pseudonana (CCMP 996) were obtained from the National Centre for Marine Algae and Microbiota (NCMA at Bigelow Laboratory, USA) and maintained under the same conditions described above.

In growth experiments, diatom growth was monitored daily in black 96-well polystyrene microplates with clear bottom (Greiner Bio-One, Germany) by measurements of relative fluorescence units (RFU) of chlorophyll using a plate reader (FLUOstar Omega, BMG, Germany) at optical filters settings of $\lambda_{\mathrm{ex}} 440-80 \mathrm{~nm}$ and $\lambda_{\mathrm{em}} 640-80 \mathrm{~nm}$. In Experiment I diatom growth and performance were further monitored by pulsed-amplitude-modulation fluorometry (Water-PAM, Walz, Germany) by measurement of the minimal $\left(F_{0}\right)$ and maximal $\left(F_{\mathrm{m}}\right)$ dark fluorescence [35]. Briefly, samples were taken $5-7 \mathrm{~h}$ into the light cycle and diluted in ESAW to be within the PAM detection range. The photosystem II (PSII) potential quantum yield $\left(F_{\mathrm{v}} / F_{\mathrm{m}}\right)$ is the normalized ratio of $F_{0}$ and $F_{\mathrm{m}}\left(\left(F_{\mathrm{m}}-F_{0}\right) / F_{\mathrm{m}}=F_{\mathrm{v}} / F_{\mathrm{m}}\right)$ and represents the maximum potential quantum efficiency [36]. The chlorophyll fluorescence readings were correlated with exact numbers of Lugol-fixed diatom cells enumerated under the microscope.

\section{Establishment of an axenic $T$. rotula culture}

The $T$. rotula_S16 culture was rendered axenic according to [37] with modifications. Briefly, $40 \mathrm{~mL}$ diatom culture was harvested at mid-exponential growth and gravity filtered onto 3- $\mu \mathrm{m}$ pore-size polycarbonate Nucleopore track-etched membrane filters (Whatman, Germany) in a sterile glass vacuum filter device. Diatoms on the filter membrane were treated sequentially with (i) $150 \mathrm{~mL}$ sterile $\mathrm{ESAW}$, (ii) $50 \mathrm{~mL}$ sterile ESAW containing $20 \mu \mathrm{gL}^{-1}$ Triton-X 100 (Sigma Aldrich, Germany), and (iii) $150 \mathrm{~mL}$ sterile ESAW. The treated cells were transferred into $100 \mathrm{~mL}$ sterile ESAW containing the antibiotics streptomycin $\left(50 \mu \mathrm{g} \mathrm{mL}^{-1}\right)$, gentamicin $\left(67 \mu \mathrm{g} \mathrm{mL}^{-1}\right)$, ciprofloxacin $\left(20 \mu \mathrm{g} \mathrm{mL}^{-1}\right)$, chloramphenicol $\left(2.2 \mu \mathrm{g} \mathrm{mL}^{-1}\right)$, and ampicillin $\left(100 \mu \mathrm{g} \mathrm{mL}^{-1}\right)$ (Sigma, Germany) and incubated for 2 days under the temperature and light settings above. Subsequently, the entire procedure was repeated twice to render the culture axenic. The axenic culture was again gravity filtered, filter washed and transferred into sterile ESAW without antibiotics at ca. 2000 cells $\mathrm{mL}^{-1}$ and grown under the temperature and light settings above. The culture was regularly checked for axenicity by nucleic acid staining with 4',6diamidino-2-phenylindole (DAPI, Thermo Fisher Scientific, Germany) under the fluorescence microscope. In parallel, the diatom culture was regularly inoculated into marine broth to check for bacterial growth and contamination.

\section{Preparation of $T$. rotula for co-culture with a bacterial inoculum}

Prior to inoculating diatoms with a defined bacterial consortium, the axenic $T$. rotula_S16 culture was depleted of vitamins. This was done by gravity filtration of $40 \mathrm{~mL}$ axenic culture at mid-exponential phase, rinsing the filter three times with $100 \mathrm{~mL}$ ESAW without vitamin 
supplements $\left(\mathrm{ESAW}^{\text {-vit }}\right)$. An aliquot of the axenic, vitaminreplete $T$. rotula_S16 culture was transferred to new ESAW ${ }^{\text {vit }}$ at 2000 cells $\mathrm{mL}^{-1}$ and maintained under temperature and light settings as described above until mid-exponential phase. These transfers were repeated until the culture no longer grew in comparison with an axenic and vitaminreplete $T$. rotula_S16 culture. The axenic and vitamindeplete $T$. rotula_S16 culture was immediately used as a recipient (in the following termed acceptor culture) of defined bacterial inocula.

\section{Preparation of the bacterial inocula}

The non-axenic diatom cultures were transferred from ESAW to $\mathrm{ESAW}^{\text {-vit }}$ for 2 months prior to their use as a source of the bacterial inoculum. Briefly, $40 \mathrm{~mL}$ culture aliquots $(n=3)$ were gravity filtered through $3-\mu \mathrm{m}(0.6 \mu \mathrm{m}$ for $T$. pseudonana) pore-size polycarbonate membranes, rinsed with $100 \mathrm{~mL} \mathrm{ESAW}^{\text {-vit }}$ and incubated in $40 \mathrm{~mL}$ $\mathrm{ESAW}^{\text {-vit }}$ for 2 days, after which the procedure was repeated twice. The logic behind this procedure was to flush freeliving, opportunistic bacteria out of the cultures. This strategy relied on the rationale that diatom-associated bacteria coexist with dissociated conspecifics. The final $40 \mathrm{~mL}$ filtrates of each diatom culture were quantified by fluorescence microscopy of DAPI-stained bacterial cells and immediately used as inoculum. The filter membranes were transferred into SL1 lysis buffer (NucleoSpin Soil ${ }^{\circledR}$ kit, Macherey Nagel, Germany) and stored at $-20^{\circ} \mathrm{C}$ for subsequent sequencing analyses of each diatom-associated bacterial community. Replicates of the $T$. rotula_S16 acceptor cultures were processed accordingly.

\section{Co-culture experiment}

Aliquots of the axenic, vitamin-deplete $T$. rotula_S16 acceptor culture were adjusted to 2000 cells $\mathrm{mL}^{-1}$ in $\mathrm{ESAW}^{\text {-vit }}$ and spiked with bacterial inocula at a ratio of 1:100 diatom:bacterial cells obtained from (i) conspecific non-axenic $T$. rotula_S16 and T. rotula_A17, (ii) congeneric T. weissflogii and T. pseudonana, (iii) heterospecific D. brightwellii and C. closterium, and (v) fresh seawater from Helgoland obtained in autumn $2017\left(54^{\circ} 11.3^{\prime} \mathrm{N}, 7^{\circ}\right.$ $54.0^{\prime}$ E). An axenic, vitamin-deplete T. rotula_S16 acceptor culture without bacterial inoculum served as the control. The co-culture experiments were run under the same temperature and light settings stated above and monitored daily for growth and performance. After 4 days, the T. rotula_S16 acceptor cultures were gravity filtered onto $3-\mu \mathrm{m}$ polycarbonate filters and transferred into lysis buffer and stored at $-20{ }^{\circ} \mathrm{C}$. The replicated co-culture experiments $(n=3)$ were done with independently prepared bacterial inocula (Experiment I) and repeated after 6 months
(Experiment II) to test if the bacterial community assembly was reproducible. In addition to Experiment I, the Experiment II included a non-diatom-derived source of the bacterial inoculum prepared from fresh seawater as well as an inoculum prepared from a fresh $T$. rotula isolate (T. rotula_A17).

\section{Bacterial DNA extraction and 16S rRNA gene sequencing}

Bacterial DNA was extracted with the NucleoSpin Soil ${ }^{\circledast}$ kit (Macherey Nagel, Germany). The filter membranes obtained in Experiment I were pooled and analyzed, whereas filters of Experiment II were analyzed individually. The DNA quantity and quality were examined with a Nanodrop (Thermo Fisher Scientific, Germany). The DNA quality was verified by electrophoresis on $1 \%$ agarose gel. The axenic T. rotula_S16 acceptor culture was processed accordingly to verify its axenicity. Bacterial DNA was amplified using an amplicon barcoded sequencing protocol for MiSeq platforms. The V4 hypervariable region of bacterial genes was amplified using modified universal bacterial primer set 515F/806R (515F: 5'-TCGTCGGCAGCGTCAGATGTGT ATAAGAGACAG GTGCCAGCMGCCGCGGTAA- ${ }^{\prime}$ and 806R: 5'-GTCTCGTGGGCTCGGAGATGTGTATAAGA GACAGGGACTACHVGGGTWTCTAAT- $3^{\prime}$ ). Each forward and reverse primer contained different barcode sequences with Illumina adapter overhang sequences as described previously $[38,39]$. The library was prepared according to the $16 \mathrm{~S}$ metagenomic sequencing library preparation script (https://support.illumina.com/downloads/ 16s_metagenomic_sequencing_library_preparation.html).

16S rRNA amplicon sequencing was subsequently performed on the Illumina MiSeq platform (Molecular Research LP; USA) following the manufacturer's guidelines. Sequence data were deposited in the European Nucleotide Archive [40], using the data brokerage service of the German Federation for Biological Data [41], in compliance with the Minimal Information about any (X) Sequence standard [42]. They are accessible under PRJEB32927.

\section{Sequence data processing and bacterial community analysis}

Sequencing was performed in $2 \times 300$-bps paired-end-mode using the MiSeq Reagent Kit v3. The trimmomatic package [43] was used to crop the 300-275 bps and a sliding window length 3 allowed an average Phred quality score of 8 to filter from $5^{\prime}$ to $3^{\prime}$ and cut when the quality dropped below the value of 8 . The paired-ends were merged with Vsearch [44] with a minimum overlap of $40 \mathrm{bps}$ and a maximum number of four mismatches. Sequences were reverse complemented and both directions merged into one file. The combined files 
were filtered for primer sequences, allowing $10 \%$ mismatch and a minimum overlap of $17 \mathrm{bps}$ for the forward and $13 \mathrm{bps}$ for the reverse primer. This step was followed by feature filtering to allow a maximum expected error per sequence of 1 , a minimum length of $275 \mathrm{bps}$, a maximum length of $475 \mathrm{bps}$ and a maximum number of ambiguities of 0 . Each sample was de-replicated independently and chimerachecked de novo. All samples were pooled and dereplicated to produce a combined dataset as input for the swarm operational taxonomic unit (OTU) clustering method under default settings [45]. The most abundant amplicon of an OTU cluster was used as representative. Sequences were annotated with the default of the ribosomal database project classifier implemented in Mothur [46]. The taxonomy was assigned with the Silva v128 reference file prepared in Mothur at a confidence level of $80 \%$. The representative annotation was used for the full OTU cluster.

\section{Statistical analyses}

To compare community profiles between different bacterial inocula and newly established bacterial consortia on $T$. rotula in Experiments I and II, mitochondrial and chloroplast reads were excluded prior to nonparametric multivariate analyses. All reads were normalized to the median sequencing depth. Principal coordinates analysis (PCoA) was performed to determine differences between bacterial community profiles on a distance matrix using Bray-Curtis similarity measures. The differences between the grouping variables (bacterial inoculum and established $T$. rotula_S16 microbiome) and among the bacterial inocula as well as among the established $T$. rotula_S16 consortia were assessed by analysis of similarity (ANOSIM). The similarity percentage procedure was applied to identify OTUs with the highest discriminating contribution score. Statistical analyses of co-culture growth states were performed using ANOVA testing followed by post hoc, pairwise comparisons of Tukey Honest Significance Difference tests. All analyses were performed with $\mathrm{R}$, version 3.4.4 (R Core Team, 2018) with Phyloseq [47] and vegan [48], and plotted with ggplot2 [49].

\section{Results}

\section{Axenification and co-culture of T. rotula_S16 with bacteria}

We demonstrated that $T$. rotula_S16 critically relied on its associated bacterial community for growth and performance. This was shown with an axenic culture stripped of its supply of vitamins $\mathrm{B}_{1}, \mathrm{~B}_{7}$, and $\mathrm{B}_{12}$. In comparison with the exponentially growing non-axenic and vitamin-deplete control, the axenic vitamin-deplete $T$. rotula culture ceased growth after 5-6 days. This coincided with a drop in potential quantum yield (Fig. 1) indicative of a decline in

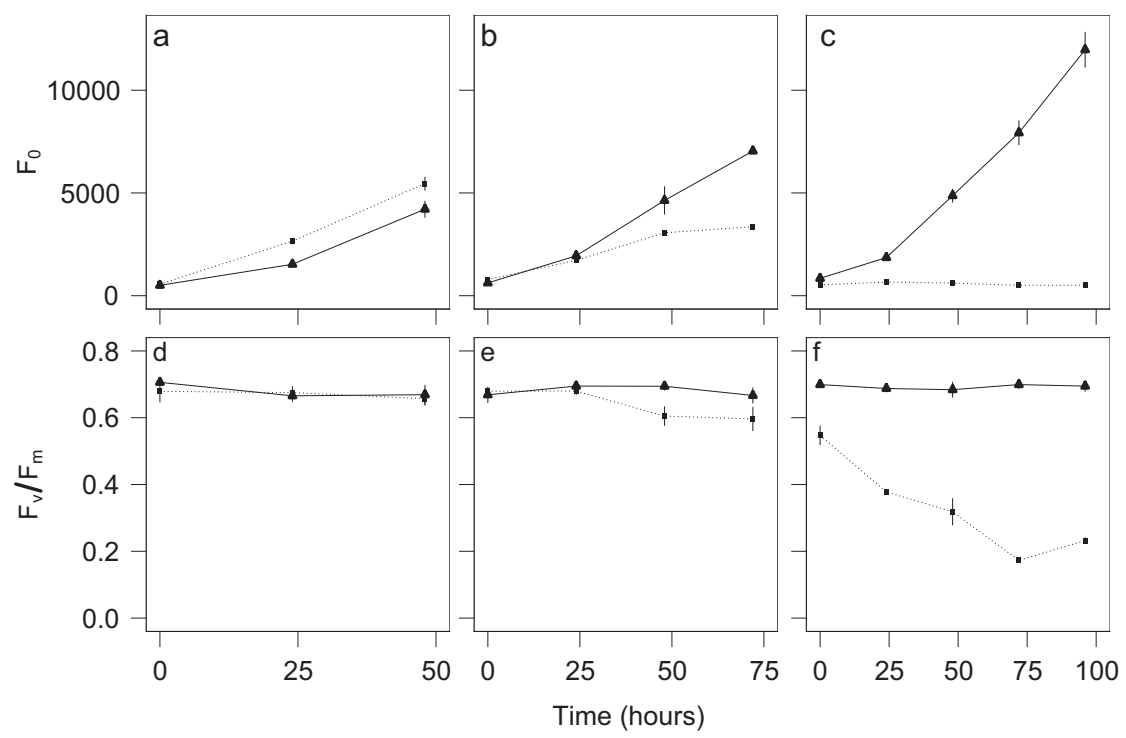

Fig. 1 Growth and performance of Thalassiosira rotula_S16 in three sequential culture transfers under axenic and non-axenic conditions. Growth $\left(F_{0}\right)(\mathbf{a}-\mathbf{c})$ and potential quantum yield $\left(F_{\mathrm{v}} / F_{\mathrm{m}}\right)$ (d-f) of an axenic (dotted line) and non-axenic (solid line) Thalassiosira rotula_S16 culture under vitamin depletion for the first $(\mathbf{a}, \mathbf{d})$, second $(\mathbf{b}, \mathbf{e})$, and third $(\mathbf{c}, \mathbf{f})$ sequential transfers into ESAW ${ }^{\text {-vit }}$ at a starting cell density of 2000 cells $\mathrm{mL}^{-1}$. At the beginning of the third transfer, the culture did no longer grow (c) and its performance dropped below that of the vitamin-replete control (f). At this stage, the axenic and vitamin-deplete $T$. rotula_S16 culture was used as acceptor in co-culture experiments with bacterial inocula. Growth was determined by minimal chlorophyll fluorescence $\left(F_{0}\right)$ and potential quantum yield using PAM fluorometry. Each data point is the result of three culture replicates with \pm 1 standard deviation indicated by vertical bars. 
PSII, supporting the well-established paradigm that a naturally associated bacterial consortium delivers essential micronutrients for diatom growth and physiological performance [50]. At day 4, the axenic $T$. rotula_S16 culture stopped growing (Fig. 1c) and was used as recipient of the bacterial inoculum. At this stage, aliquots of the axenic, vitamin-deplete $T$. rotula_S16 culture were then inoculated and cultured with several complex bacterial consortia.

\section{Co-culture of axenic T. rotula_S16 with diverse bacterial inocula}

In co-culture Experiment I, T. rotula_S16 inoculated with its conspecific bacterial assemblage (Fig. 2, solid line) grew equally well as the non-axenic vitamin-deplete control (Fig. 2, dashed line) and reached mid-exponential phase after 4 days. The axenic $T$. rotula_S16 culture was stagnant at this time (Fig. 2, dotted line). The T. rotula_S16 cultures inoculated with congeneric and heterospecific diatom bacterial assemblages in Experiments I and II grew the same or statistically better than $T$. rotula_S16 inoculated with its conspecific bacterial community (Fig. 2 and Supplementary Table S1). The only exceptions to this trend were $T$. rotula_S16 cultures inoculated with a bacterial assemblage of the conspecific autumn 2017 isolate T. rotula_A17 and seawater which induced significantly higher growth than the axenic control but significantly lower growth than all other inoculated cultures.

\section{Sequence analysis and comparison of community structures in bacterial inocula and established T. rotula_S16 bacterial consortia}

Comparative sequence analyses of the 16S rRNA gene libraries revealed a total number of 5 million raw reads across all replicates after quality filtering (Supplementary Fig. S1). The replicates of Experiment I were pooled prior to sequencing whereas the independent replicates of Experiment II were individually sequenced. The individual bacterial inoculum communities differed significantly among each other (ANOSIM: $R=0.751, p<0.001$ ), whereas all established $T$. rotula bacterial consortia were statistically the same $(R=0.133, p=0.084)$. This was also reflected in the clustering pattern obtained by PCoA (Fig. 4). While significant $(p<0.001)$ the differences between the community profiles of the bacterial inocula (containing 13-2071 OTUs) and the established $T$. rotula bacterial consortia (containing 11-80 OTUs, Table S2) were low as revealed by an $\mathrm{R}$ score of 0.154 . This is likely due to the overlap of few OTUs shared across all communities, such as OTU-7, $-11,-29,-30,-2,-12$, and -33 (Fig. 5, panel 2). The most diverse bacterial inoculum was obtained from seawater containing 2071 OTUs. Of all bacterial
T. rotula_S16 I

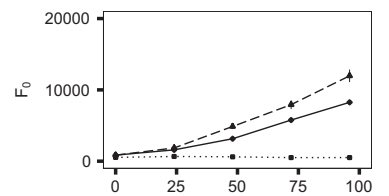

C. closterium

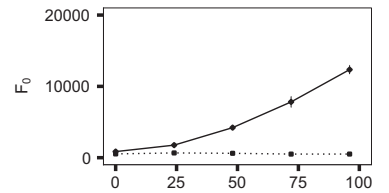

T. weissflogii

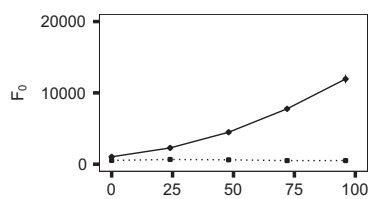

T. pseudonana

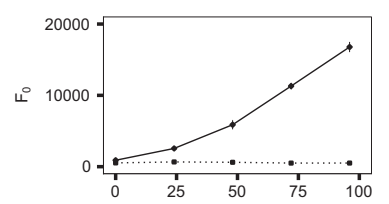

D. brightwellii

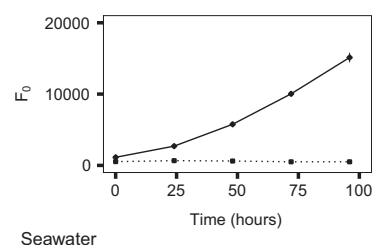

Seawater

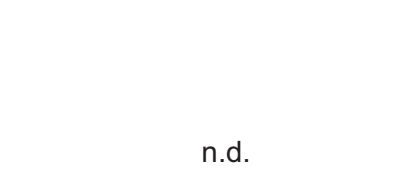

T. rotula_A17

n.d.
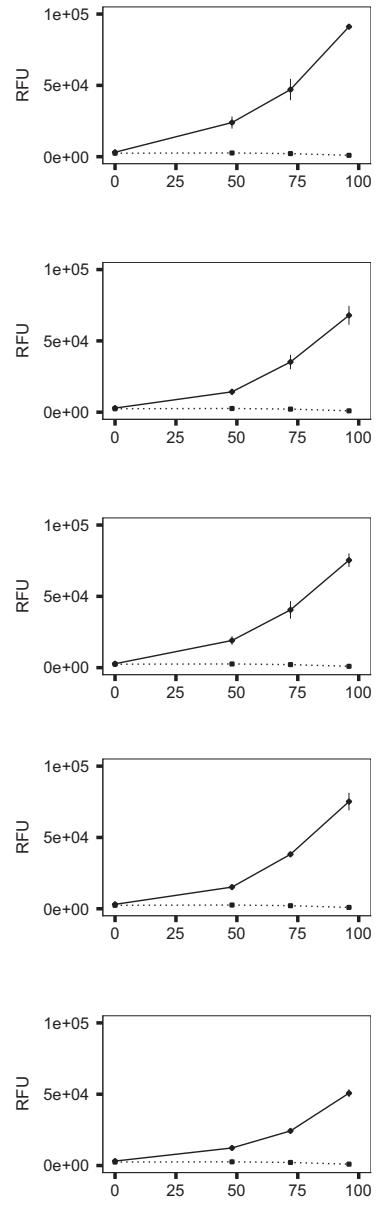

T.

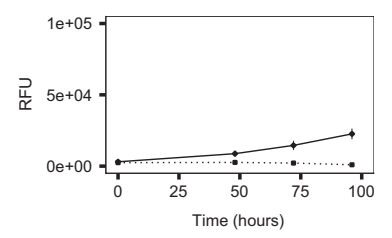

Fig. 2 Co-culture of axenic Thalassiosira rotula_S16 with different bacterial inocula. Growth of T. rotula_S16 acceptor cultures (solid black line) in Experiments I (left column) and II (right column) inoculated with bacterial communities obtained from $T$. rotula_S16, Cylindrotheca closterium, T. weissflogii, T. pseudonana, Ditylum brightwellii, seawater, and T. rotula_A17 (the latter two only in Experiment II). A non-axenic vitamin-deplete $T$. rotula_S16 culture served as positive control in Experiment I (dashed line, top panel), an axenic vitamin-deplete $T$. rotula_S16 culture (dotted line) served as negative control. In Experiment I, growth was determined by minimal chlorophyll fluorescence $\left(F_{0}\right)$. Due to faster readings, relative fluorescence (RFU) was used as a unit of growth in Experiment II. Each data point is the result of three culture replicates with \pm 1 standard deviation indicated by vertical bars. n.d. (not determined). 
OTUs in the established T. rotula bacterial consortia, $79.5 \%$ were Proteobacteria and 2.4\% Bacteroidetes.

The different community structures of the bacterial inocula and the established $T$. rotula bacterial consortia were also apparent by PCoA (Fig. 4). There was high similarity between both conspecific bacterial inocula obtained from $T$. rotula_S16 and T. rotula_A17 and their corresponding established bacterial consortia. The other bacterial consortia resulting from inoculation of $T$. rotu$l a \_$S16 with congeneric and heterospecific bacterial communities clustered closely with the conspecific established T. rotula_S16 bacterial consortia (Fig. 4).

The established bacterial consortia were characterized by 27 OTUs responsible for a cumulative abundance of $94 \%$. The most dominant OTUs were OTU-7 (Alteromonas sp.), OTU-8 (unclassified), OTU-13 (Marinomonas sp.), and OTU-11 (Sulfitobacter sp.). These four OTUs alone contributed $60 \%$ to the overall reads in established $T$. rotula bacterial consortia (Fig. 5, panel 1).

When individually comparing the abundances of 27 OTUs in the inocula and established $T$. rotula bacterial consortia, three cases could be distinguished (Fig. 5, panel 2). Either an OTU was abundant in both, the inoculum as well as the established community (e.g., OTU-7). More often, OTUs were hardly abundant in the inoculum whereas abundant in the established community (e.g., OTU-8, -13, $-54,-37,-49,-43,-57$, and -59$)$. Differences of highly abundant OTUs in the inoculum versus low abundance in the established community were also observed (e.g., OTU$30,-2,-12,-33,-17$, and -27$)$.

\section{Discussion}

The outside of marine macroorganisms is commonly covered with microbial biofilms. These epibiotic microbial assemblages affect macroorganisms in various ways causing a range of positive and negative impacts [51]. While host-microbe interactions play fundamental roles in marine ecosystems, we have little understanding of the ecological processes that govern these relationships, the evolutionary processes that shape them and their synecological consequences. Cumulative evidence suggests that epibiotic microbial communities are characteristic to their living hosts $[52,53]$. Yet, compared with a number of detailed microbiome studies of multicellular marine macroalgae $[22,52,54-56]$, there is currently no unifying scheme or theory for bacterial community assembly on unicellular algae that underpins the divergent observations of distinct core communities on phylogenetically different microalgae to spatially and/or temporally diverse communities on conspecific microalgae [57].
To better understand the bacterial community assembly on ecologically relevant phytoplankton, we defined a model diatom that can be cultured and experimentally manipulated under controlled conditions. We chose the cosmopolitan marine diatom $T$. rotula in co-culture with bacterial communities detached from other diatoms of varying degrees of relatedness to the axenic Thalassiosira host or seawater. Compared with its well-studied brackish congener T. pseudonana $[58,59], T$. rotula is a marine bloom-forming diatom of global abundance and significance [29, 30].

The co-cultures reached mid-exponential growth at the same time as the non-axenic control (Fig. 2 and Supplementary Table S1), suggesting that the newly established primary bacterial consortia support the same synecological function as the original microbiome of the non-axenic vitamin-deplete $T$. rotula control. Given that all diatoms used in this study are reported to have an absolute vitamin $\mathrm{B}_{12}$ requirement for growth [60-62], this further suggests that at least some bacteria in the different inocula (and seawater) possess vitamin synthesis capabilities. A future experimental setup resulting from these conclusions would inoculate the model system with bacterial consortia obtained from a diatom reported to lack an absolute $B_{12}$ requirement, such as Phaeodactylum tricornutum, which has a flexible cobalamin demand because its genome encodes both cobalamin-dependent and independent methionine synthase [62]. In this case we would not expect to observe a growth promoting effect of an axenic, vitamindeplete $T$. rotula culture.

\section{Phylogenetic composition of bacterial inoculum communities}

In support of recent studies, the phylogenetic composition of associated bacterial consortia among the various diatoms differed significantly $[2,18,19,63]$. The consortia were dominated by Alteromonadaceae and Rhodobacteraceae, which is in agreement with prior studies [2, 19]. The phylogenetically most diverse bacterial community was obtained from seawater, which is consistent with studies comparing free-living and particle-associated bacteria (including those associated with algae) [50,64]. The repeated sequence analyses of bacterial consortia on diatoms sampled 6 months apart were highly reproducible (Figs. 3 and 4). Such strong conservation across strains cultivated from different seasons is in agreement with recent studies [16]. The T. rotula isolates obtained in spring 2016 and autumn 2017 revealed different bacterial consortia, with the autumn isolate rich in Cryomorphaceae and Oceanospirillaceae while lacking Colwelliaceae (Fig. 3). Similar observations of the influence of season on the bacterial community structure have been made with other conspecific diatoms [21]. 


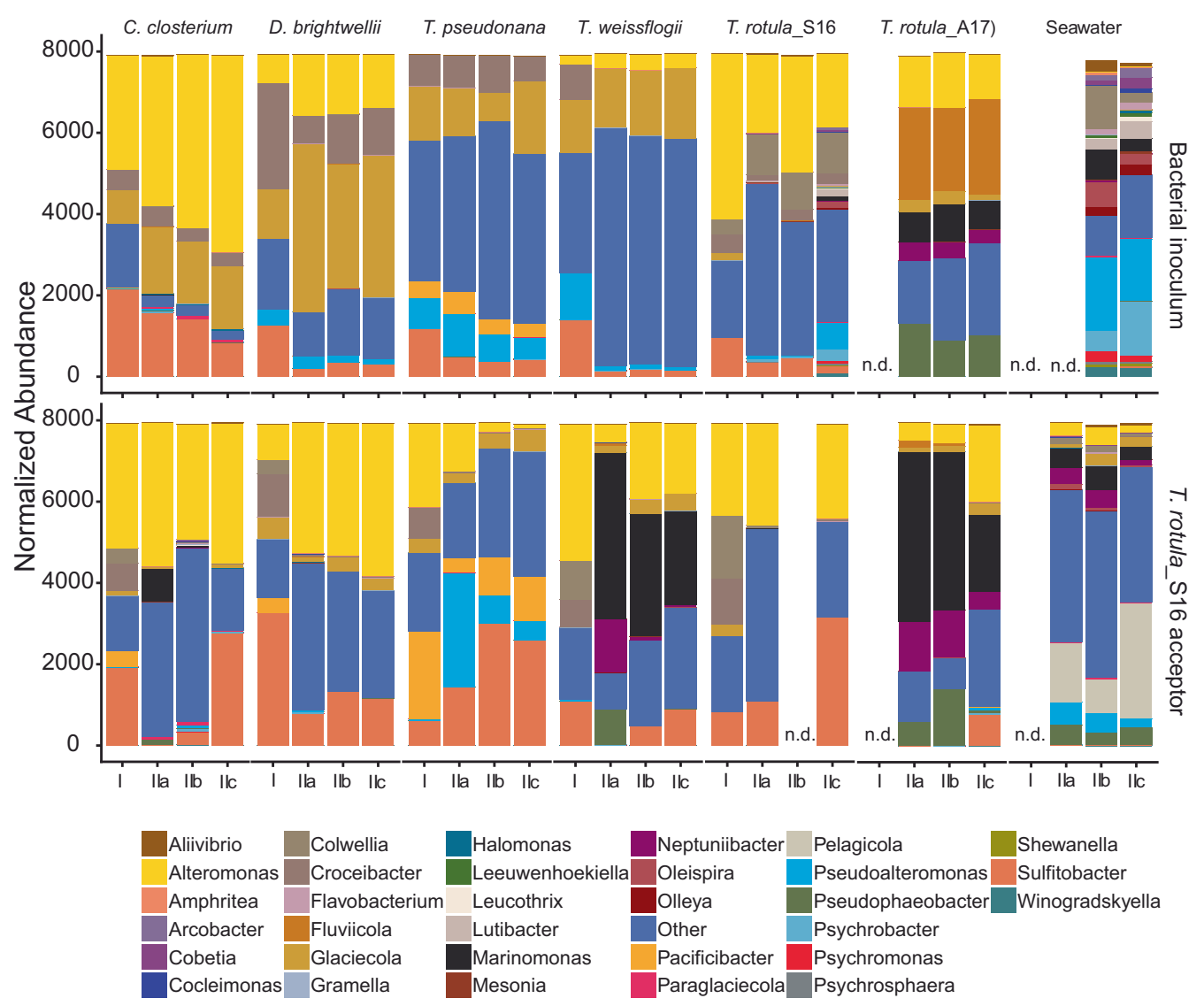

Fig. 3 Phylogenetic composition of established T. rotula_S16 bacterial consortia (bottom row) and bacterial inoculum communities detached from different diatoms and seawater (top row). The stacked bar plots show the normalized abundance of OTUs at the genus level. The pooled replicates of Experiment I are denoted as (I). Individual replicates $(\mathrm{a}, \mathrm{b}, \mathrm{c})$ of Experiment II are denoted as (IIa-c). n.d. (not determined).

\section{Phylogenetic composition of established $T$. rotula bacterial consortia}

The bacteria in the different inocula were presumably adapted to a diatom-associated life style, yet the newly established $T$. rotula_S16 bacterial consortia consisting of 11-80 OTUs were statistically different from these source communities (Fig. 4). Notably, the established T. rotula bacterial consortia were compositionally and quantitatively most similar to each of their corresponding conspecific source community (i.e., T. rotula strains S16 and A17), thus validating the experimental approach of effectively dissociating and re-establishing their diatom-specific bacterial consortia (Fig. 4).

Overall, the co-culture experiment revealed a convergent assembly of highly diverse and compositionally different bacterial communities (consisting of 13-2071 OTUs) towards a rather defined and reduced $T$. rotula core community. Even the most diverse community, seawater, containing 2071 OTUs, was reduced to this core community, dominated by Rhodobacteraceae (30.5\%), Alteromonadaceae (27.7\%), and Oceanospirillales (18.5\%) (Figs. 3 and 4).
Fig. 4 Principle coordinate analysis (PCoA) of bacterial community compositions in established Thalassiosira rotula_S16 bacterial consortia (triangles) and bacterial inocula (squares) obtained from non-axenic $T$. rotula_S16, T. rotula_A17, T. weissflogii, T. pseudonana, Ditylum brightwellii, Cylindrotheca closterium, and seawater. Treatments of Experiment I and II are denoted by open (I) and closed (II) symbols, respectively. 

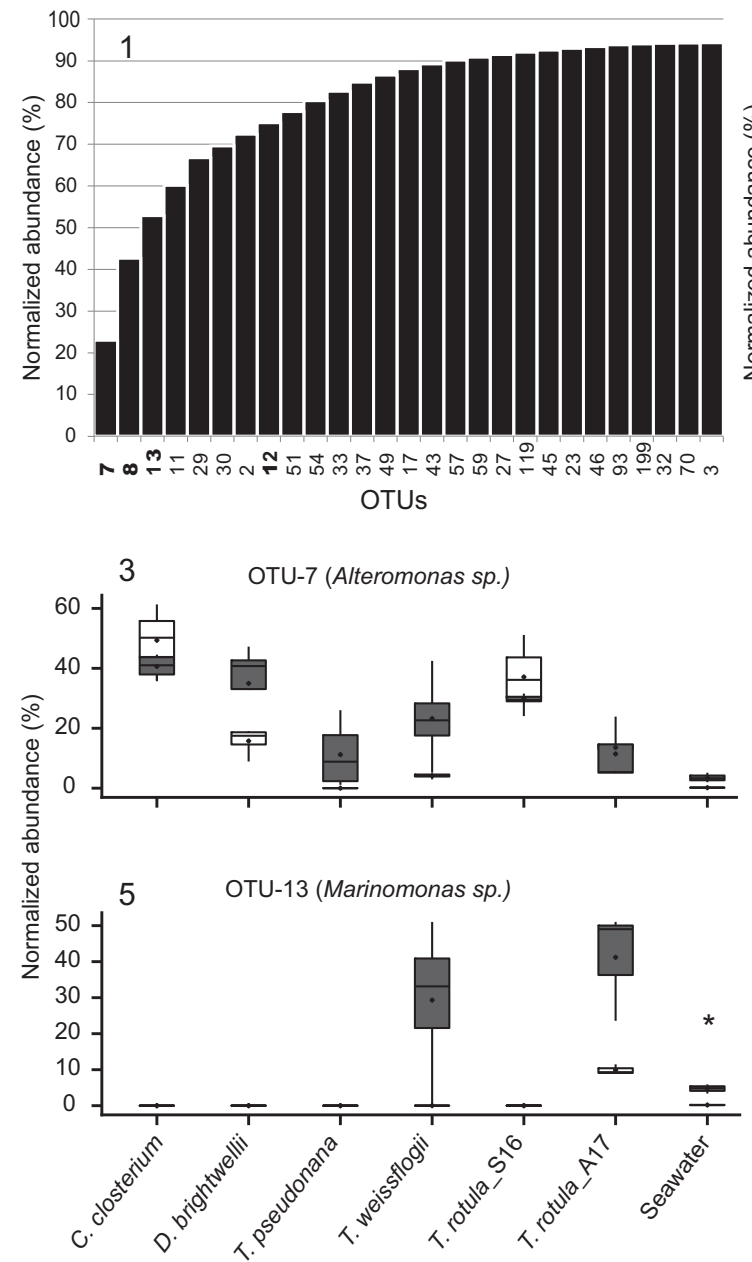

Fig. 5 Abundance and contribution of OTUs to the Thalassiosira rotula core microbiome. Panel 1 Cumulative normalized abundance of 27 OTUs comprising $94 \%$ of the established T. rotula bacterial consortia (bold OTU numbers are presented in panel 3-6). Panel 2 Comparison of individual OTU abundances averaged across all inocula (gray bars) and established acceptor bacterial consortia (black

The differences in relative abundance of certain OTUs in the established bacterial consortia compared with the inoculum were either the same (indicating neutral uptake), significantly higher (indicating favorable uptake), or significantly lower (indicating disadvantageous uptake) (Fig. 5, panel 2-6). The most drastic qualitative and quantitative transition from the inoculum to the core community was observed in the co-culture setup of a seawater bacterial community with the axenic $T$. rotula culture, supporting a parallel study using seawater bacterioplankton as inoculum with axenic $T$. rotula [65].

Our experimental setup was based on the hypothesis that all bacteria in the different inocula (except for the seawater community) possessed the genetic and metabolic abilities to colonize the axenic $T$. rotula surface and be sustained on diatom-derived organic carbon. The strong phylogenetic convergence and high degree of overlap among comparatively
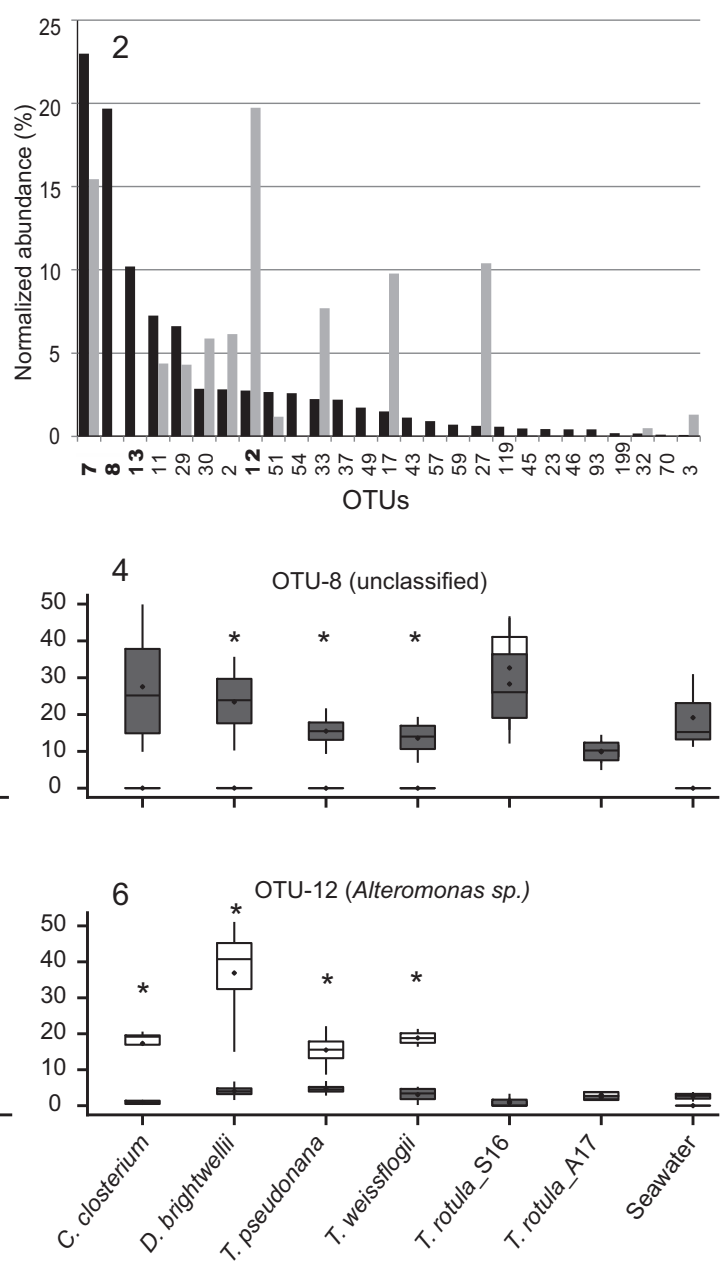

bars). Panel 3-6 Normalized abundance of OTU-7, -8, -13, and -12 in individual bacterial inocula (white box plots) and corresponding established $T$. rotula bacterial consortia (gray box plots). Significant differences in OTU abundances between bacterial inocula and established consortia are marked with an asterisk.

few OTUs shared across the established $T$. rotula bacterial consortia was instead indicative of a highly selected, stable, and reproducible core bacterial community. This conclusion was further supported by the diverse seawater bacterial community converging to statistically the same characteristic community structure (Figs. 3 and 4). Remarkably, despite high statistical similarity among all established $T$. rotula_S16 bacterial consortia, the $T$. rotula_S16 cultures inoculated with bacteria obtained from $T$. rotula_A17 and seawater, both sampled in autumn 2017, revealed significantly lower growth than the other co-cultures (Fig. 2). Since both of these established consortia clustered closely by PCoA (Fig. 4), these results suggest that even small differences in the overall community composition can significantly affect the diatom host performance.

Together, these data reject the hypothesis that the bacterial consortium assembly on $T$. rotula is due to stochastic 
recruitment according to the lottery hypothesis. Instead, bacterial colonization of the diatom results from a reproducible selection pattern of individual OTUs from the inoculum into the corresponding established consortia. This clearly suggests a steering force or "habitat filtering effect" [66]. The host diatom is likely to drive the initial filtering or selection, providing nutritional conditions that promote the growth of certain microbes over others. Indeed, the low-molecular weight sugars and amino acids released by diatoms are the chemical cues that allow flagellated and chemotactic bacterial groups such as Rhodobacteraceae, Alteromonadaceae, and Oceanospirillales to be enriched within the phycosphere and potentially interact with the HMW substratum (e.g., polysaccharides) to which biofilm cells adhere. It is moreover possible that host traits act in tandem with feedback loops between the host and microbes, e.g., via the release of antibacterial compounds [67, 68], as well as among microbes $[65,69]$, allowing the establishment of a predictable assemblage of OTUs in the community.

In our study, the 4-day-old primary $T$. rotula bacterial consortium was compositionally highly similar to the inoculum sourced from an established, several month-old donor culture, suggesting that the bacterial core community indeed represents a long-term stable-state system. Our findings are in contrast to a recent comparative study [65] demonstrating a shift in the $T$. rotula associated bacterial composition over a time course of 8 days, possibly due to changes in the host physiology (e.g., growth and metabolism).

Cumulatively, the co-culture experiment used in this study offers experimental evidence that initial bacterial epibiosis of the marine model diatom $T$. rotula is characteristically underpinned by the niche-based diatom microscale environment and bacterial species-specific metabolic characteristics resulting in a remarkably stable and reproducible bacterial core community. This knowledge in tandem with further investigations of the role and function of stable core bacterial members is crucial when studying the performance and resilience of the diatom holobiont in the context of environmental change. The feedback between the marine carbon cycle and ocean warming make such dynamic hotspots for the microbial loop critical interactions to consider in light of our rapidly impacted oceans.

Acknowledgements We thank Nancy Kühne for technical advice and assistance with the molecular laboratory work, and Stefan Kühne for assistance in bioinformatics. Open access funding provided by Projekt DEAL.

\section{Compliance with ethical standards}

Conflict of interest The authors declare that they have no conflict of interest.
Publisher's note Springer Nature remains neutral with regard to jurisdictional claims in published maps and institutional affiliations.

Open Access This article is licensed under a Creative Commons Attribution 4.0 International License, which permits use, sharing, adaptation, distribution and reproduction in any medium or format, as long as you give appropriate credit to the original author(s) and the source, provide a link to the Creative Commons license, and indicate if changes were made. The images or other third party material in this article are included in the article's Creative Commons license, unless indicated otherwise in a credit line to the material. If material is not included in the article's Creative Commons license and your intended use is not permitted by statutory regulation or exceeds the permitted use, you will need to obtain permission directly from the copyright holder. To view a copy of this license, visit http://creativecommons. org/licenses/by/4.0/.

\section{References}

1. Buchan A, LeCleir GR, Gulvik CA, González JM. Master recyclers: features and functions of bacteria associated with phytoplankton blooms. Nat Rev Microbiol. 2014;12:686-98.

2. Amin SA, Parker MS, Armbrust EV. Interactions between diatoms and bacteria. Microbiol Mol Biol Rev. 2012;76:667-84.

3. Rooney-Varga JN, Giewat MW, Savin MC, Sood S, LeGresley M, Martin JL. Links between phytoplankton and bacterial community dynamics in a coastal marine environment. Micro Ecol. 2005;49:163-75.

4. Haines KC, Guillard RRL. Growth of vitamin B12-requiring marine diatoms in mixed laboratory cultures with vitamin B12producing marine bacteria. J Phycol. 1974;10:245-52.

5. Amin SA, Green DH, Hart MC, Küpper FC, Sunda WG, Carrano CJ. Photolysis of iron-siderophore chelates promotes bacterial-algal mutualism. Proc Natl Acad Sci. 2009;106: 17071-6.

6. Croft MT, Lawrence AD, Raux-Deery E, Warren MJ, Smith AG. Algae acquire vitamin B-12 through a symbiotic relationship with bacteria. Nature. 2005;438:90-3.

7. Myklestad SM. Release of extracellular products by phytoplankton with special emphasis on polysaccharides. Sci Total Environ. 1995;165:155-64.

8. Wetz MS, Wheeler PA. Release of dissolved organic matter by coastal diatoms. Limnol Oceanogr. 2007;52:798-807.

9. Aluwihare LI, Repeta DJ. A comparison of the chemical characteristics of oceanic DOM and extracellular DOM produced by marine algae. Mar Ecol Prog Ser. 1999;186:105-17.

10. Christie-Oleza JA, Sousoni D, Lloyd M, Armengaud J, Scanlan DJ. Nutrient recycling facilitates long-term stability of marine microbial phototroph-heterotroph interactions. Nat Microbiol. 2017;2:17100.

11. Amin SA, Hmelo LR, van Tol HM, Durham BP, Carlson LT, Heal $\mathrm{KR}$, et al. Interaction and signalling between a cosmopolitan phytoplankton and associated bacteria. Nature. 2015;522:98-101.

12. Seymour JR, Amin SA, Raina JB, Stocker R. Zooming in on the phycosphere: the ecological interface for phytoplankton-bacteria relationships. Nat Microbiol. 2017;2:17065.

13. Rossi F, De Philippis R. Exocellular polysaccharides in microalgae and cyanobacteria: chemical features, role and enzymes and genes involved in their biosynthesis. In: Borowitzka M, Beardall J, Raven J, editors. The physiology of microalgae. Developments in applied phycology 6. New York: Springer; 2016. p. 565-90.

14. Mühlenbruch M, Grossart H-P, Eigemann F, Voss M. Minireview: phytoplankton-derived polysaccharides in the marine environment and their interactions with heterotrophic bacteria. Environ Microbiol. 2018;20:2671-85. 
15. Lombard V, Golaconda Ramulu H, Drula E, Coutinho PM, Henrissat B. The carbohydrate-active enzymes database (CAZy) in 2013. Nucleic Acids Res. 2014;42:490-5.

16. Behringer G, Ochsenkühn MA, Fei C, Fanning J, Koester JA, Amin SA. Bacterial communities of diatoms display strong conservation across strains and time. Front Microbiol. 2018;9:659.

17. Frischkorn KR, Rouco M, Van Mooy BAS, Dyhrman ST. Epibionts dominate metabolic functional potential of Trichodesmium colonies from the oligotrophic ocean. ISME J. 2017;11:2090-101.

18. Krohn-Molt I, Alawi M, Förstner KU, Wiegandt A, Burkhardt L, Indenbirken $\mathrm{D}$, et al. Insights into microalga and bacteria interactions of selected phycosphere biofilms using metagenomic, transcriptomic, and proteomic approaches. Front Microbiol. 2017; 8:1941.

19. Sapp M, Schwaderer AS, Wiltshire KH, Hoppe H-G, Gerdts G, Wichels A. Species-specific bacterial communities in the phycosphere of microalgae? Micro Ecol. 2007;53:683-99.

20. Abby SS, Touchon M, De Jode A, Grimsley N, Piganeau G. Bacteria in Ostreococcus tauri cultures-friends, foes or hitchhikers? Front Microbiol. 2014;5:505.

21. Ajani PA, Kahlke T, Siboni N, Carney R, Murray SA, Seymour JR. The microbiome of the cosmopolitan diatom leptocylindrus reveals significant spatial and temporal variability. Front Microbiol. 2018;9:2758.

22. Burke C, Thomas T, Lewis M, Steinberg P, Kjelleberg S. Composition, uniqueness and variability of the epiphytic bacterial community of the green alga Ulva australis. ISME J. 2011;5: 590-600.

23. Naeem S. Species redundancy and ecosystem reliability. Conserv Biol. 1998;12:39-45.

24. Munday PL. Competitive coexistence of coral-dwelling fishes: the lottery hypothesis revisited. Ecology. 2004;85:623-8.

25. Sale PF. Reef fish lottery. Nat Hist. 1976;85:60-5.

26. Burke C, Steinberg P, Rusch D, Kjelleberg S, Thomas T. Bacterial community assembly based on functional genes rather than species. Proc Natl Acad Sci. 2011;108:14288-93.

27. Baker LJ, Kemp PF. Exploring bacteria diatom associations using single-cell whole genome amplification. Aquat Micro Ecol. 2014;72:73-88.

28. Crenn K, Duffieux D, Jeanthon C. Bacterial epibiotic communities of ubiquitous and abundant marine diatoms are distinct in shortand long-term associations. Front Microbiol. 2018;9:2879.

29. Malviya S, Scalco E, Audic S, Vincent F, Veluchamy A, Poulain $\mathrm{J}$, et al. Insights into global diatom distribution and diversity in the world's ocean. Proc Natl Acad Sci. 2016;113:1516-25.

30. Whittaker KA, Rignanese DR, Olson RJ, Rynearson TA. Molecular subdivision of the marine diatom Thalassiosira rotula in relation to geographic distribution, genome size, and physiology. BMC Evol Biol. 2012;12:209.

31. Harrison PJ, Waters RE, Taylor FJR. A broad-spectrum artificial seawater medium for coastal and open ocean phytoplankton. J Phycol. 1980;16:28-35.

32. Medlin L, Elwood HJ, Stickel S, Sogin ML. The characterization of enzymatically amplified eukaryotic 16S-like rRNA-coding regions. Gene. 1988;71:491-9.

33. Scholin CA, Herzog M, Sogin M, Anderson DM. Identification of group- and strain-specific genetic markers for globally distributed Alexandrium (Dinophaceae). II. Sequence analysis of the fragment of the LSU rRNA gene. J Phycol. 1994;30:999-1011.

34. Kraberg A, Baumann M, Dürselen C. Coastal phytoplanktonphoto guide for northern European seas. München: Verlag Dr. Friedrich Pfeil; 2010.

35. Bramucci AR, Labeeuw L, Mayers TJ, Saby JA, Case RJ. A small volume bioassay to assess bacterial/phytoplankton co-culture using WATER-Pulse-Amplitude-Modulated (WATER-PAM) fluorometry. J Vis Exp. 2015. https://doi.org/10.3791/52455: 52455.

36. Vankooten O, Snel JFH. The use of chlorophyll fluorescence nomenclature in plant stress physiology. Photosynthesis Res. 1990;25:147-50.

37. Shishlyannikov SM, Zakharova YR, Volokitina NA, Mikhailov IS, Petrova DP, Likhoshway YV. A procedure for establishing an axenic culture of the diatom Synedra acus subsp radians (Kutz.) Skabibitsch from Lake Baikal. Limnol Oceanogr Methods. 2011;9:478-84.

38. Caporaso JG, Lauber CL, Walters WA, Berg-Lyons D, Huntley J, Fierer N, et al. Ultra-high-throughput microbial community analysis on the Illumina HiSeq and MiSeq platforms. ISME J. 2012;6: 1621-4.

39. Klindworth A, Pruesse E, Schweer T, Peplies J, Quast C, Horn M, et al. Evaluation of general $16 \mathrm{~S}$ ribosomal RNA gene PCR primers for classical and next-generation sequencing-based diversity studies. Nucleic Acids Res. 2013;41:11.

40. Toribio AL, Alako B, Amid C, Cerdeño-Tarrága A, Clarke L, Cleland I, et al. European nucleotide archive in 2016. Nucleic Acids Res. 2016;45:32-6.

41. Diepenbroek M, Glöckner F, Grobe P, Güntsch A, Huber R, König-Ries B, et al. Towards an integrated biodiversity and ecological research data management and archiving platform: the German Federation for the Curation of Biological Data (GFBio) In: Plödereder E, Grunske L, Schneider E, Ull D, editors. Informatik 2014-Big Data Komplexität meistern. GI-Edition: Lecture Notes in Informatics (LNI)-Proceedings. GI edn. 232. Bonn: Köllen Verlag; 2014. p. 1711-24.

42. Yilmaz P, Kottmann R, Field D, Knight R, Cole JR, AmaralZettler $\mathrm{L}$, et al. Minimum information about a marker gene sequence (MIMARKS) and minimum information about any $(\mathrm{x})$ sequence (MIxS) specifications. Nat Biotechnol. 2011;29:415.

43. Bolger AM, Lohse M, Usadel B. Trimmomatic: a flexible trimmer for Illumina sequence data. Bioinformatics. 2014;30:2114-20.

44. Rognes T, Flouri T, Nichols B, Quince C, Mahe F. VSEARCH: a versatile open source tool for metagenomics. PeerJ. 2016;4:22.

45. Mahe F, Rognes T, Quince C, de Vargas C, Dunthorn M. Swarm: robust and fast clustering method for amplicon-based studies. PeerJ. 2014;2:13.

46. Wang Q, Garrity GM, Tiedje JM, Cole JR. Naive Bayesian classifier for rapid assignment of rRNA sequences into the new bacterial taxonomy. Appl Environ Microbiol. 2007;73:5261-7.

47. McMurdie PJ, Holmes S. phyloseq: an R package for reproducible interactive analysis and graphics of microbiome census data. PLoS One. 2013;8:11.

48. Oksanen J, Blanchet FG, Friendly M, Kindt R, Legendre P, McGlinn D, et al. Vegan: community ecology package. R package version 2.5-1. 2018. https://cran.r-project.org/web/packages/vega $\mathrm{n} / \mathrm{index} \cdot \mathrm{html}$.

49. Wickham H. ggplot2: Elegant graphics for data analysis. New York, NY: Springer; 2009.

50. Grossart H-P, Levold F, Allgaier M, Simon M, Brinkhoff T. Marine diatom species harbour distinct bacterial communities. Environ Microbiol. 2005;7:860-73.

51. Harder T. Marine epibiosis: concepts, ecological consequences and host defence. In: Flemming H-C, Murthy PS, Venkatesan R, Cooksey K, editors. Marine and industrial biofouling. Berlin, Heidelberg: Springer Berlin Heidelberg; 2009. p. 219-31. https:// doi.org/10.1007/978-3-540-69796-1_12.

52. Lachnit T, Meske D, Wahl M, Harder T, Schmitz R. Epibacterial community patterns on marine macroalgae are host-specific but temporally variable. Environ Microbiol. 2011;13:655-65.

53. Pita L, Rix L, Slaby BM, Franke A, Hentschel U. The sponge holobiont in a changing ocean: from microbes to ecosystems. Microbiome. 2018;6:46. 
54. Barott KL, Rodriguez-Brito $\mathrm{B}$, Janouškovec J, Marhaver KL, Smith JE, Keeling P, et al. Microbial diversity associated with four functional groups of benthic reef algae and the reef-building coral Montastraea annularis. Environ Microbiol. 2011;13:1192-204.

55. Egan S, Harder T, Burke C, Steinberg P, Kjelleberg S, Thomas T. The seaweed holobiont: understanding seaweed-bacteria interactions. FEMS Microbiol Rev. 2013;37:462-76.

56. Vieira C, Engelen AH, Guentas L, Aires T, Houlbreque F, Gaubert $\mathrm{J}$, et al. Species specificity of bacteria associated to the brown seaweeds lobophora (Dictyotales, Phaeophyceae) and their potential for induction of rapid coral bleaching in acropora muricata. Front Microbiol. 2016;7:316.

57. Wietz M, Lau SC, Harder T. Editorial: socio-ecology of microbes in a changing ocean. Front Mar Sci. 2019;6:190. https://doi.org/ 10.3389/fmars.2019.00190.

58. Alverson AJ, Beszteri B, Julius ML, Theriot EC. The model marine diatom Thalassiosira pseudonana likely descended from a freshwater ancestor in the genus Cyclotella. BMC Evol Biol. 2011;11:125.

59. Armbrust EV, Berges JA, Bowler C, Green BR, Martinez D, Putnam NH, et al. The genome of the diatom Thalassiosira pseudonana: ecology, evolution, and metabolism. Science. 2004; 306:79-86.

60. Croft MT, Warren MJ, Smith AG. Algae need their vitamins. Eukaryot Cell. 2006;5:1175-83.

61. Grossart H-P. Interactions between marine bacteria and axenic diatoms (Cylindrotheca fusiformis, Nitzschia laevis, and Thalassiosira weissflogii) incubated under various conditions in the lab. Aquat Micro Ecol. 1999;19:1-11.
62. Helliwell KE, Wheeler GL, Leptos KC, Goldstein RE, Smith AG. Insights into the evolution of vitamin B12 auxotrophy from sequenced algal genomes. Mol Biol Evol. 2011;28:2921-33.

63. Lupette J, Lami R, Krasovec M, Grimsley N, Moreau H, Piganeau $\mathrm{G}$, et al. Marinobacter dominates the bacterial community of the Ostreococcus tauri phycosphere in culture. Front Microbiol. 2016;7:1414.

64. DeLong EF, Franks DG, Alldredge AL. Phylogenetic diversity of aggregate-attached vs. free-living marine bacterial assemblages. Limnol Oceanogr. 1993;38:924-34.

65. Majzoub ME, Beyersmann PG, Simon M, Thomas T, Brinkhoff T, Egan S. Phaeobacter inhibens controls bacterial community assembly on a marine diatom. FEMS Microbiol Ecol. 2019;95: fiz060.

66. Costello EK, Stagaman K, Dethlefsen L, Bohannan BJM, Relman DA. The application of ecological theory toward an understanding of the human microbiome. Science. 2012;336:1255-62.

67. Qin J, D'Antignanal T, Zhang W, Franco C. Discovery of antimicrobial activities of a marine diatom Thalassiosira rotula. Afr J Microbiol Res. 2013;7:10.

68. Wichard T, Gerecht A, Boersma M, Poulet SA, Wiltshire K, Pohnert G. Lipid and fatty acid composition of diatoms revisited: rapid wound-activated change of food quality parameters influences herbivorous copepod reproductive success. ChemBioChem. 2007;8:1146-53.

69. Longford SR, Campbell AH, Nielsen S, Case RJ, Kjelleberg S, Steinberg PD. Interactions within the microbiome alter microbial interactions with host chemical defences and affect disease in a marine holobiont. Sci Rep. 2019;9:1363. 